\title{
Pengenalan Pola Tulisan Tangan Suku Kata Aksara Sasak Menggunakan Metode Moment Invariant dan Support Vector Machine
}

\author{
(Handwritten Sasak Ancient Script Recognition using Moment Invariant and Support \\ Vector Machine)
}

\author{
Riska Yulianti*, I Gede Pasek Suta Wijaya, dan Fitri Bimantoro \\ Prodi. Teknik Informatika, Fakultas Teknik, Universitas Mataram \\ Jl. Majapahit 62, Mataram, Lombok NTB, INDONESIA \\ Email: riskakayulianti@gmail.com,gpsutawijaya@unram.ac.id,bimo@unram.ac.id
}

*Penulis korespondensi

\begin{abstract}
The research of Javanese and Balinese ancient script has been done by some researches. However, researches still have problems, such as image scaling, noise reduction, and image transformation. This research implemented a moment invariant and support vector machine to solve these problems especially on Sasak ancient script. The input data used in this research was 2700 handwritten Sasak ancient script. The testing was done to know the effect of thinning and the number of features by using zoning on the classification performance. Accuracy is used as a performance indicator. The highest average accuracy is $89.76 \%$, in the second scenario, the average accuracy obtained is $92.52 \%$.
\end{abstract}

Key Words: image thinning, zoning, sasak ancient script, moment invariant, $S V M$

\section{PENDAHULUAN}

Aksara merupakan suatu simbol visual yang tertera pada suatu media (kertas, kain) untuk mengungkapkan unsur-unsur yang ekspresif dalam suatu bahasa. Aksara digunakan untuk secara khusus menuliskan bahasa daerah tertentu. Salah satu bahasa daerah nusantara yang digunakan di Lombok adalah bahasa Sasak dan ditulis dengan menggunakan aksara Sasak[1].

Aksara Sasak adalah salah satu aksara tradisional nusantara yang berkembang di Lombok, Nusa Tenggara Barat dan terdiri dari 18 suku kata yang diadaptasi dari aksara Jawa dan Bali. Beberapa penelitian dilakukan untuk membahas mengenai aksara nusantara termasuk di dalamnya aksara Jawa dan aksara Bali yang berasal dari satu rumpun yang sama dengan aksara Sasak. Penelitian sebelumnya membahas mengenai aksara Jawa dan Bali yang menghasilkan akurasi klasifikasi sebesar 38\% hingga $80 \%$. Penelitian tersebut dihadapkan oleh beberapa permasalahan yaitu tranformasi citra [2], perbedaan skala citra[3], dan noise reduction[4]. Pada penelitian ini menggabungkan 2 metode yang belum pernah dilakukan pada penelitian sebelumnya yaitu Moment Invariant dan SVM. Metode Moment Invariant dikenal menghasilkan ciri geometri objek dari pengenalan karakter yang independen terhadap translasi, rotasi dan penskalaan citra sedangkan metode SVM merupakan metode learning machine yang bekerja atas prinsip Structural Risk Minimization dengan tujuan menemukan hyperplane terbaik yang memisahkan 2 buah kelas pada input space. Berdasarkan teori dari kedua metode tersebut diharapkan penggabungan keduanya dapat mengenali pola tulisan tangan suku kata aksara Sasak dengan tepat serta mengatasi permasalahan yang dihadapi pada penelitian sebelumnya.

\section{TINJAUAN PUSTAKA}

Pada penelitian terdahulu yang terkait dengan penelitian ini yaitu penelitian mengenai pengenalan tulisan yang dibangun dengan menggunakan metode Logika Fuzzy dan jaringan saraf tiruan memiliki tingkat pengenalan sebesar 84,1\% [5]. Penelitian serupa telah dilakukan membahas tentang pengenalan wajah dengan penggabungan Moment Invariant dan Backpropagation Neural Network. Hasil akurasi dari penelitian tersebut adalah 98,22\%[6]. Penelitian ini menunjukkan bahwa Moment Invariant sangat baik digunakan dalam ekstraksi fitur.

Penelitian selanjutnya yang mendukung penelitian sebelumnya yaitu penelitian mengenai pengenalan huruf alphabet yang normal. Hasil akurasi data latih mencapai $90 \%$ dan angka rata-rata pengenalan sebesar 79,5\% dengan huruf kecil dengan font Times New Roman yang diputar 90 derajat dan 270 derajat memiliki presentase terkecil dengan $57,7 \%$. Pengenalan mencapai angka 90\% ketika diputar 180 derajat baik huruf kapital maupun huruf kecil untuk semua jenis huruf [7].

Penelitian yang terkait dengan penelitian ini juga telah dilakukan dan menunjukkan bahwa metode Moment Invariant dapat digunakan untuk memperoleh matrik berdimensi rendah sehingga mempercepat waktu komputasi [8]. Penelitian berikutnya mengenai metode SVM yang digunakan dalam proses pengklasifikasian citra, terdapat penelitian terdahulu yang mendukung metode 
tersebut yaitu penelitianuntuk membangun suatu aplikasi pengenalan wajah. Hasil penelitiannya didapat bahwa keberhasilan metode klasifikasi SVM untuk basis data Yale mencapai $100 \%$ dan untuk basis data ORL mencapai 95\%. [9]. Penelitian lain yang mendukung proses pengklasifikasian menggunakan metode SVM yaitu penelitian pengklasifikasian warna kulit berdasarkan ras dengan menggunakan metode SVM memberikan akurasi sebesar 92,5\% [10]. Hasil akurasi dari kedua penelitian ini menunjukkan bahwa aplikasi pengenalan wajah dengan menggunakan metode klasifikasi SVM merupakan sebuah aplikasi yang cukup handal.

Berdasarkan tinjauan pustaka tersebut, dapat diketahui bahwa pengenalan pola menggunakan metode Moment Invariant dan SVM memiliki tingkat keberhasilan mencapai lebih dari $70 \%$. Untuk itu, dibuat suatu hipotesa bahwa penelitian ini akan memberikan hasil yang maksimal dalam pengenalan pola aksara Sasak.

\section{A. Aksara Sasak}

Aksara Sasak atau hanacaraka adalah salah satu aksara tradisional nusantara yang berkembang di Lombok, Indonesia dan terdiri dari 18 suku kata. Aksara ini digunakan untuk menulis bahasa daerah yaitu Bahasa Sasak [1]. Keseluruhan suku kata aksara Sasak tertera pada Gambar 1.

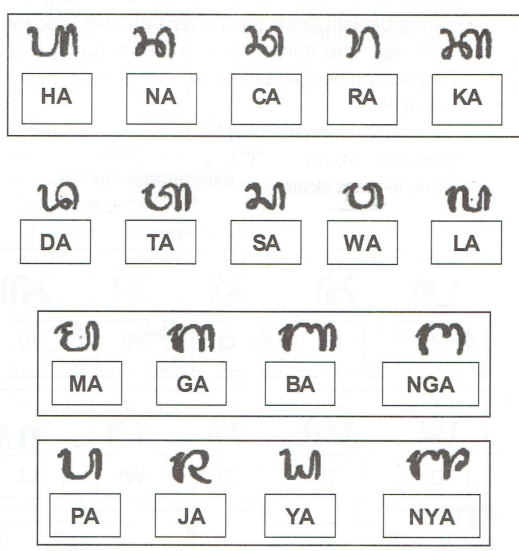

Gambar 1. Suku kata aksara Sasak

\section{B. Image Thinning}

Image thinning adalah proses morpologi citra yang merubah bentuk asli citra biner menjadi citra yang menampilkan batas-batas obyek atau foreground hanya setebal satu piksel. Algoritma thinning secara iterative menghapus piksel-piksel pada citra biner, dimana transisi dari 0 ke 1 (atau dari 1 ke 0 ) terjadi sampai dengan terpenuhi suatu keadaan dimana satu himpunan dari lebar per-unit (satu pixel) terhubung menjadi suatu garis. Tujuan image thinning adalah untuk menghilangkan piksel-piksel yang berada didalam obyek depan pada citra biner [11]. Ilustrasi dari proses thinning yang dilakukan pada penelitian ini dapat dilihat pada Gambar 2.
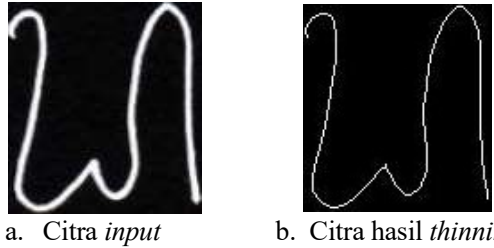

Gambar 2. Image thinning

b. Citra hasil thinning

\section{Zoning}

Zoning citra karakter dapat dibagi ke dalam zona $\mathrm{n} \mathrm{x}$. Setiap zona memiliki fitur yang diekstraksi ke dalam vektor fitur. Tujuan dilakukan proses zoning adalah untuk mendapatkan nilai karakteristik per bagian yang merupakan karakteristik citra karakter secara global [12]. Proses zoning pada paper ini disajikan pada Gambar 3.

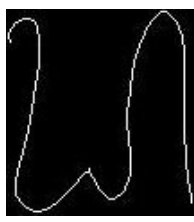

a. Citra input

Gambar 3. Image zoning

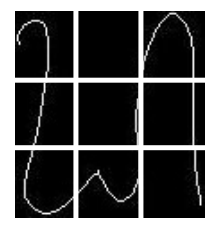

b. Citra hasil zoning

\section{Moment Invariant}

Moment Invariant merupakan fungsi non-linear yang invariant terhadap rotasi, translasi dan skala dalam moment geometri citra. Jika ada sebuah citra dengan nilai intensitas adalah $\mathrm{f}(\mathrm{x}, \mathrm{y})$ nilai $\mathrm{x}$ sebagai baris dan y sebagai kolom maka Moment Invariant yang mentransformasikan fungsi citra $\mathrm{f}(\mathrm{x}, \mathrm{y})$ pada sistem diskrit [9].

dimana :

$$
m_{p q}=\sum_{x=0}^{W-1} x \quad \sum_{y=0}^{H-1} y x^{p} y^{q} f(x, y)
$$

$$
\begin{array}{ll}
m & =\text { Moment } \text { Citra } \\
p, q & =\text { Orde Moment } \\
\mathrm{f} \quad=\text { Nilai intensitas warna citra } \\
\mathrm{x}, \mathrm{y}=\text { Koordinat piksel } \\
H, W \quad \text { = Tinggi dan lebar citra } .
\end{array}
$$

Moment citra yang invariant terhadap translasi citra adalah dengan orde $\mathrm{m} 00, \mathrm{~m} 01, \mathrm{~m} 02, \mathrm{~m} 03, \mathrm{~m} 10, \mathrm{~m} 11, \mathrm{~m} 12$, $\mathrm{m} 20,21, \mathrm{~m} 31$. Selanjutnya, ditentukan koordinat pusat citra berdasarkan moment citra yang dihitung dengan menggunakan Persamaan (2) dan Persamaan (3).

$$
\begin{aligned}
& \bar{x}=\frac{m_{10}}{m_{00}} \\
& \bar{y}=\frac{m_{01}}{m_{00}}
\end{aligned}
$$

m00 adalah jumlah total piksel yang membentuk obyek, sedangkan m10 dan m11 adalah pusat massa obyek. Selanjutnya untuk memperoleh moment invariant terhadap rotasi maka moment pusat diperoleh dengan menggunakan Persamaan (4).

dimana :

$$
\mu_{p q}=\sum_{x} x \sum_{y} y(x-\bar{x})^{p}(y-\bar{y})^{q}
$$

$$
\begin{aligned}
& \mu=\text { Moment Pusat } \\
& \bar{x}, \bar{y}=\text { Pusat Citra }
\end{aligned}
$$


Moment pusat yang terbentuk sensitif terhadap transformasi rotasi dan penskalaan. Maka dnmi it.. dilakukan normalisasi terhadap moment pusat (5) melalui Persamaan (5) dan Persamaan (6).

$$
\begin{aligned}
& \eta_{p q}=\frac{\mu_{p q}}{\mu_{00}^{\gamma}} \\
& \gamma=\left(\frac{p+q}{2}\right)+1
\end{aligned}
$$

Berdasarkan normalisasi moment pusat dapat dihitung tujuh vector moment invariant dengan Persamaan (7) sampai dengan Persamaan (13).

$$
\begin{aligned}
\varphi 1= & \eta_{20}+\eta_{02} \\
\varphi 2= & \left(\eta_{20}-\eta_{02}\right)^{2}+4 \eta_{11}^{2} \\
\varphi 3= & \left(\eta_{03}-3 \eta_{12}\right)^{2}+\left(3 \eta_{21}-\eta_{03}\right)^{2} \\
\varphi 4= & \left(\eta_{30}-3 \eta_{12}\right)^{2}+\left(3 \eta_{21}+3 \eta_{03}\right)^{2} \\
\varphi 5= & \left(\eta_{30}-3 \eta_{12}\right)^{2}\left(\eta_{30}-3 \eta_{12}\right)^{2}\left[\left(\eta_{30}+\eta_{12}\right)^{2}\right. \\
& \left.3\left(\eta_{21}+\eta_{03}\right)^{2}\right]+\left(3 \eta_{21}-\eta_{03}\right)^{2}\left(\eta_{21}+\right. \\
& \left.\eta_{03}\right)^{2}\left[3\left(\eta_{30}-\eta_{12}\right)^{2}-\left(\eta_{21}-\eta_{03}\right)^{2}\right] \\
\varphi 6= & \left(\eta_{20}-\eta_{02}\right)^{2}\left[\left(\eta_{30}+\eta_{12}\right)^{2}-\left(\eta_{21}+\eta_{03}\right)^{2}\right] \\
& \left(4 \eta_{11}\left(\eta_{30}+\eta_{12}\right)\left(\eta_{21}+\eta_{03}\right)\right. \\
\varphi 7= & \left(3 \eta_{21}-\eta_{03}\right)\left(\eta_{30}+\eta_{12}\right)\left[\left(\eta_{30}+\eta_{12}\right)^{2}-\right. \\
& \left.3\left(\eta_{21}+\eta_{03}\right)^{2}\right]+\left(3 \eta_{12}-\eta_{30}\right)\left(\eta_{21}+\right. \\
& \left.\eta_{03}\right)\left[3\left(\eta_{30}+\eta_{12}\right)^{2}-\left(\eta_{21}-\eta_{03}\right)^{2}\right]
\end{aligned}
$$

\section{E. Support Vector Machine}

SVM merupakan metode learning machine dengan prinsip kerja Structural Risk Minimization (SRM). Tujuan dari SVM ini adalah menemukan hyperplane terbaik yang memisahkan dua buah kelas pada ruang input. SVM adalah sistem pembelajaran yang menggunakan ruang hipotesa berupa fungsi-fungsi linier dalam sebuah ruang fitur berdimensi tinggi.

Teknik SVM berkaitan dengan data mining maupun machine learning karena memiliki kemampuan dalam memprediksi kelas suatu data baru. Berikut pembahasan dengan kasus klasifikasi yang secara linier bisa dipisahkan

Fungsi pemisah untuk model SVM pada paper ini adalah fungsi linier. Fungsi ini didefinisikan sebagai:

$$
f(x)=w \cdot x+b
$$

Setiap data latih dinyatakan oleh $\left(x_{\mathrm{i}}, y_{\mathrm{i}}\right)$, d1 mana $i=1,2, \ldots, N$, dan $x_{\mathrm{i}}=\left\{x_{\mathrm{i} 1}, x_{\mathrm{i} 2}, \ldots, x_{\mathrm{i}} q\right\}^{T}$ merupakan fitur set untuk data latih ke-i. $y_{\mathrm{i}} \in\{-1,+1\}$ menyatakan label kelas. Hyperplane klasifikasi linier SVM, seperti pada Gambar 2.7, dinotasikan dengan:

$$
w \cdot x_{i}+b=0
$$

$W$ dan $b$ adalah parameter model. w. $x_{i}$ merupakan inner-product dalam antara $w$ dan $x_{i}$. Data $x_{i}$ yang masuk ke dalam kelas -1 adalah data yang memenuhi pertidaksamaan berikut:

$$
w \cdot x_{i}+b \leq-1
$$

Sementara data $x_{i}$ yang masuk ke dalam kelas +1 adalah data yang memenuhi pertidaksamaan berikut :

$$
w \cdot x_{i}+b \geq+1
$$

\section{Metode PEnElitian}

\section{A. Alat dan Bahan}

Alat yang diperlukan pada penelitian ini adalah :

1. Hardware Laptop: menggunakan Intel $\AA$ Core $i 3 \AA$ CPU 2020, $2.4 \mathrm{GHz}$, RAM 2 GB

2. Operating system: menggunakan Operating System Windows 10 Ultimate 64-bit.

3. Software java: menggunakan software Netbeans IDE 8.0 diperlukan untuk pembuatan program dengan menggunakan bahasa pemrograman Java.

4. Scanner Canon LiDE 120. Resolusi 2400 dpi. Maksimum kertas letter.

Sedangkan bahan yang diperlukan adalah sebagai berikut:

1. Tulisan tangan suku kata aksara Sasak ditulis oleh 15 orang berbeda sebanyak 10 kali sehingga jumlahnya adalah $15 \times 10 \times 18=2700$ tulisan tangan, ditulis pada kertas putih menggunakan alat tulis yang sama.

2. Citra aksara Sasak dalam format JPEG diperoleh dari hasil scanning tulisan tangan aksara Sasak yang berukuran maksimal 300x300 piksel.

\section{B. Rancangan Sistem}

Perancangan sistem merupakan tahap yang penting dalam mengaplikasikan suatu konsep agar dalam pembuatannya dapat berjalan secara sistematis, terstruktur, dan rapi sehingga hasil program dapat berjalan sesuai dengan apa yang dikehendaki. Proses perancangan sistem tertuang dalam Gambar 4.

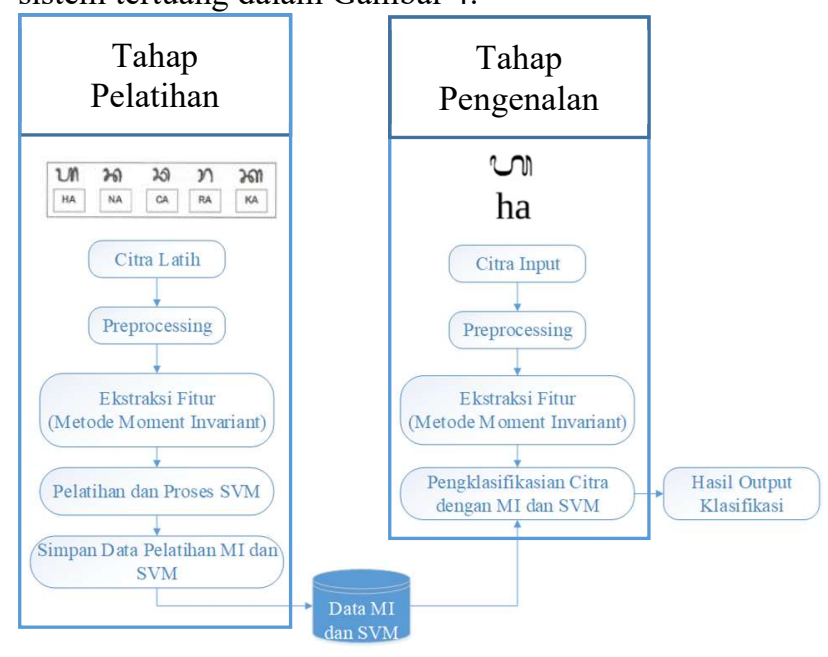

Gambar 4. Blok Diagram Sistem

Secara umum Gambar 4 menggambarkan proses pengenalan sistem, yang terdiri atas 2 tahapan utama yaitu pelatihan dan pengenalan.

\section{B.1 Tahap Pelatihan}

Proses pelatihan bertujuan untuk menemukan model sistem pengenalan citra huruf sasak dengan parameter optimalnya. Proses ini terdiri atas beberapa sub-proses, yaitu: 
1. Input Citra Latih: Menyiapkan citra digital tulisan tangan 18 suku kata aksara Sasak untuk proses pelatihan. Contoh citra input seperti pada Gambar 5.

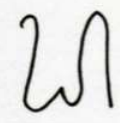

Gambar 5. Citra input tahap pelatihan

2. Preprocessing: Preprocessing merupakan tahap awal pengolahan citra asli sebelum citra tersebut diekstraksi pada proses pelatihan maupun pengklasifikasian yang dimaksudkan untuk memanipulasi citra agar sesuai dengan hasil yang diinginkan. Blok diagram dari preprocessing dapat dilihat pada Gambar 6. Pada proses ini digunakan data citra dari 18 suku kata aksara Sasak. Data citra tersebut merupakan citra dengan tipe RGB dan format JPG. Proses preprocessing dimulai dengan melakukan proses resizing untuk mengubah ukuran citra input menjadi $28 \times 28$ piksel. Kemudian citra hasil resizing tersebut di manipulasi dengan melakukan proses grayscaling. Grayscaling citra dilakukan dengan cara mengambil semua piksel pada gambar kemudian warna tiap piksel akan diambil informasi mengenai 3 warna dasar yaitu merah, biru dan hijau. Ketiga warna dasar ini akan dijumlahkan kemudian dibagi tiga sehingga didapat nilai rata-rata. Nilai rata-rata inilah yang akan dipakai untuk memberikan warna pada piksel gambar sehingga warna menjadi grayscale. Hasil citra grayscaling kemudian di konversi menjadi format biner dengan proses binarization. Setelah proses binarization kemudian dilakukan proses cropping dengan tujuan memotong noise pada citra biner sehingga diperoleh citra hasil cropping berupa informasi citra tanpa adanya noise atau universe of discourse. Hasil cropping citra kemudian di resize kembali menjadi ukuran $28 \times 28$ piksel. Citra hasil resize tersebut kemudian dilakukan proses thinning untuk memperoleh informasi penting dari citra berupa kerangka (skeleton). Jadi hasil yang diperoleh dari proses preprocessing berupa citra biner thinning dengan ukuran $28 \times 28$ piksel.

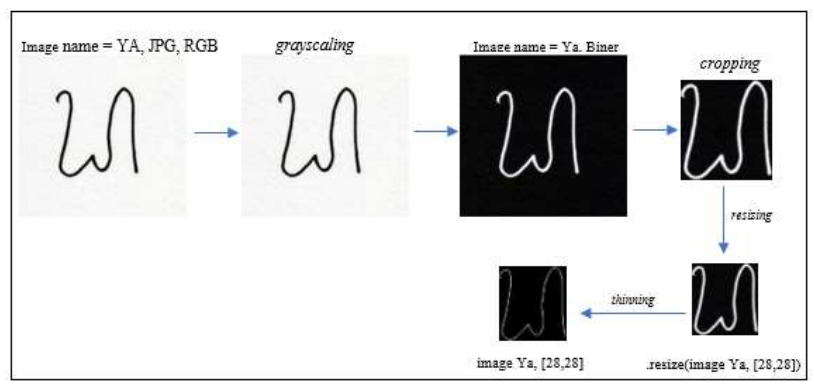

Gambar 6. Proses preprocessing pada tahap pelatihan

3. Ekstraksi Fitur: Melakukan ekstraksi fitur dengan menggunakan metode Moment Invariant pada citra data latih. Hasil yang diperoleh dari proses ekstraksi fitur ini adalah tujuh nilai moment invariant.

4. Pelatihan SVM: Melakukan pelatihan SVM untuk mendapatkan bobot data latih yang dapat digunakan untuk mengenali atau mengklasifikasikan aksara Sasak. Secara sederhana, proses pelatihan ditunjukkan pada Gambar 7. Gambar 7 menunjukan bahwa citra input hasil preprocessing berupa citra biner dengan ukuran 28x28 piksel. Citra ini kemudian dilanjutkan ke dalam proses ekstraksi fitur menggunakan perhitungan metode Moment Invariant sesuai dengan Persamaan (7) hingga (13) sehingga diperoleh nilai fitur berupa 7 buah nilai Moment Invariant. Setelah didapatkan nilai fitur data dimasukkan pada libSVM. Hasil proses pelatihan disimpan dalam format $\mathrm{xml}$ sebagai Data Set SVM. Pembagian kelas dalam SVM menggunakan tree structure. Pada proses pertama, 18 buah kelas dikelompokkan sebagai 2 kelas. Kelas pertama merupakan setengah bagian dari jumlah aksara Sasak (9 suku kata) yang memiliki kemiripan fisik satu sama lain. Pada proses kedua, aksara selain dari aksara yang berada di kelas pertama menjadi bagian dari kelas kedua, sehingga diperoleh 2 buah kelas dari kedua proses tersebut. Proses ini terus berlanjut hingga diperoleh kelas untuk 1 suku kata aksara Sasak. Library yang digunakan yaitu openCV. Arsitektur SVM disimpan dalam bentuk xml sehingga didapatkan 17 buah xml dari hasil pelatihan.

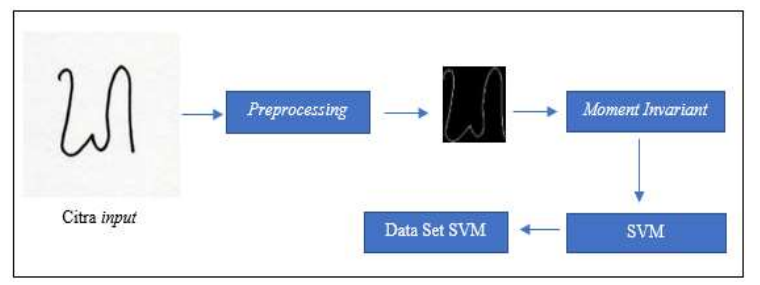

Gambar 7. Proses pelatihan SVM

5. Simpan data pelatihan MI dan SVM: hasil dari proses ektraksi dan proses pelatihan SVM akan disimpan sebagai bobot data latih.

\section{B.2 Tahap Pengenalan}

Merupakan tahapan untuk mengenali setiap citra masukkan kedalam kelas tertentu yang bersesuaian dengan data kelas pelatiha. Sub-proses dari tahpan pengenalan yaitu:

1. Input Citra: Memasukkan data citra tulisan tangan suku kata aksara Sasak (Gambar 8) yang akan di klasifikasi ke dalam sistem.

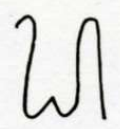

Gambar 8. Citra input tahap pengenalan

2. Preprocessing: Melakukan proses yang bertujuan untuk mengubah besar citra digital sehingga memiliki ukuran yang sama. Hasil yang diperoleh dalam proses 
preprocessing ini adalah citra biner thinning dengan ukuran 28x28 piksel. Algoritma preprocessing disajikan pada Gambar 9.

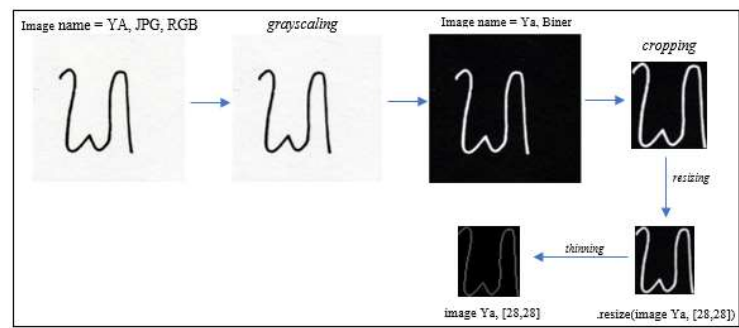

Gambar 9. Proses preprocessing pada tahap pengenalan

3. Ekstraksi Fitur: Melakukan ekstraksi fitur dengan menggunakan metode Moment Invariant sehingga diperoleh tujuh nilai moment invariant.

4. Pengklasifikasian Citra dengan MI dan SVM: Melakukan klasifikasi berdasarkan hasil ekstraksi fitur citra input tulisan tangan aksara sasak dengan metode SVM yang alurnya ditunjukkan pada Gambar 10

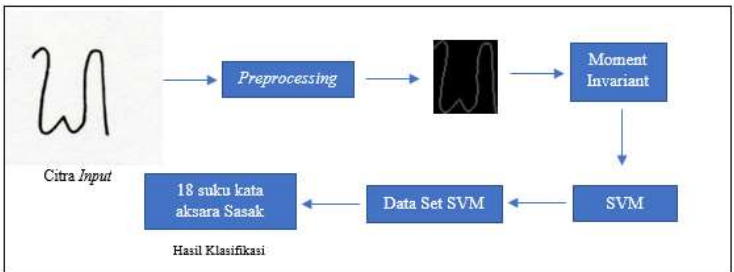

Gambar 10. Alur proses pengenalan

Setelah didapatkan nilai fitur dengan metode Moment Invariant, SVM akan membaca kembali data set SVM (xml) yang telah disimpan sebelumnya pada proses pelatihan. Illustrasi klasifikasi SVM ditunjukkan pada Gambar 11 dan 12.

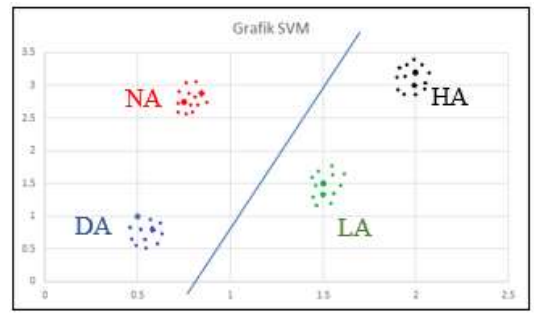

Gambar 11. Ilustrasi garis klasifikasi SVM pertama

Pada SVM pertama akan dilakukan pengklasifikasian antara kelas 1 (9 suku kata pertama) dengan kelas 2 (9 suku kata kedua). Jika hasil menunjukan citra merupakan kelas 1 maka proses klasifikasi dilanjutkan ke SVM berikutnya. Perilaku serupa dilakukan jika hasil menunjukan citra merupakan kelas 2 maka proses klasifikasi dilanjutkan pada SVM berikutnya. Pada SVM kedua akan dilakukan pengklasifikasian antara kelas 1 (NA) dengan kelas (DA). Jika respon bernilai 1 maka citra terklasifikasi sebagai kelas NA dan sebaliknya jika respon bernilai 1 maka citra terklasifikasi sebagai kelas DA. Perilaku serupa dilakukan jika hasil menunjukan citra merupakan kelas 2(HA) dengan kelas (LA). Jika respon bernilai -1 maka citra terklasifikasi sebagai kelas HA dan sebaliknya jika respon bernilai 1 maka citra terklasifikasi sebagai kelas LA.

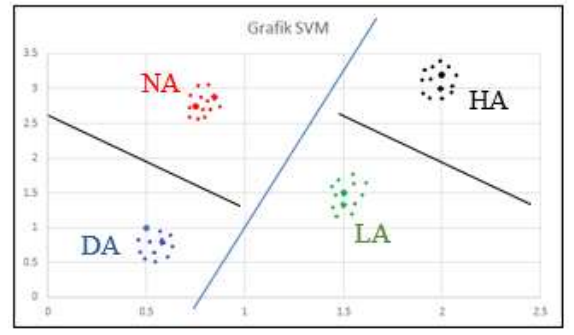

Gambar 12. Ilustrasi garis klasifikasi SVM kedua

5. Hasil Output Klasifikasi: Diperoleh hasil keluaran klasifikasi aksara Sasak berupa huruf latin citra asli aksara Sasak.

\section{Teknik Pengujian}

Teknik pengujian yang digunakan oleh sistem harus diuji dengan parameter-parameter statistik yang dikumpulkan. Parameter-parameter tersebut meliputi tingkat akurasi. Tingkat akurasi merupakan nilai kesesuaian antara input-an dengan hasil klasifikasi. Untuk menghitung parameter akrurasi digunakan Persamaan (18).

dimana,

$$
\text { Akurasi }=\frac{T P+T}{T P+T N+F P+F N} \times 100 \%
$$

TP (True Positive): banyaknya hasil klasifikasi benar untuk suatu kelas yang bernilai positive,

TN (True Negative): banyaknya hasil klasifikasi benar untuk suatu kelas yang bernilai negative,

FP (False Positive) adalah banyaknya hasil klasifikasi salah untuk suatu kelas yang bernilai negative.

FN (False Negative) adalah banyaknya hasil klasifikasi salah untuk suatu kelas yang bernilai positive

Dalam penentuan presisi data latih dan data uji digunakan pendekatan $K$-Fold Cross Validation. K-Fold Cross Validation adalah pendekatan yang digunakan untuk mengestimasi performa atau kualitas suatu model. Cara bekerjanya dengan membagi sebuah data sampel menjadi $\mathrm{k}$ bagian secara acak dan sama besarnya. Satu bagian akan menjadi datu uji dan model akan melakukan fitting terhadap $\mathrm{k}$ bagian lainnya. Proses ini dilakukan sebanyak $\mathrm{k}$ kali menggunakan $\mathrm{k}$ validation yang berbeda.

\section{HASIL DAN PEMBAHASAN}

Pengujian terhadap sistem dilakukan secara offline. Tujuan dari pengujian ini adalah untuk mengetahui nilai akurasi yang diberikan oleh metode Moment Invariant dalam proses ekstraksi fitur dan SVM dalam pengklasifikasian citra.

\section{A. Pengujian}

Proses pengujian dilakukan dalam 2 skenario berbeda yaitu :

1. Skenario pengujian pertama: Pada proses pelatihan, data yang digunakan yaitu 10x10x18=1800 data latih 
maka untuk proses pengujian data yang digunakan yaitu $10 \times 5 \times 18=900$ data uji.

2. Skenario pengujian kedua: Proses pengujian menggunakan K-Fold Cross Validation dengan menggunakan total data sampel yaitu $15 \times 10 \times 18=$ 2700 data sampel dimana $\mathrm{K}$ yang digunakan sebanyak 10 K-Fold. Tabel I menunjukkan tahapan pengujian dengan menggunakan K-Fold Cross Validation.

TABEL I. TAHAP PENGUJIAN K-FOLD

\begin{tabular}{|c|c|c|c|c|}
\hline Tahap 1 & Tahap 2 & Tahap 3 & Tahap 4 & Tahap 5 \\
\hline Fold1 test & Fold2 test & Fold3 test & Fold4 test & Fold5 test \\
\hline Fold2 train & Fold3 train & Fold4 train & Fold5 train & Fold6 train \\
\hline Fold3 train & Fold4 train & Fold5 train & Fold6 train & Fold7train \\
\hline Fold4 train & Fold5 train & Fold6 train & Fold7 train & Fold8 train \\
\hline Fold5 train & Fold6 train & Fold7 train & Fold8 train & Fold9 train \\
\hline Fold6 train & Fold7 train & Fold8 train & Fold9 train & Fold10 train \\
\hline Fold7 train & Fold8 train & Fold9 train & Fold10train & Fold1 train \\
\hline Fold8 train & Fold9 train & Fold10train & Fold1 train & Fold2 train \\
\hline Fold9 train & Fold10train & Fold1 train & Fold2 train & Fold3 train \\
\hline Fold10 train & Fold1 train & Fold2 train & Fold3 train & Fold4 train \\
\hline Tahap 6 & Tahap 7 & Tahap 8 & Tahap 9 & Tahap 10 \\
\hline Fold6 test & Fold7 test & Fold8 test & Fold9 test & Fold10 test \\
\hline Fold7 train & Fold8 train & Fold9 train & Fold10 train & Fold1 train \\
\hline Fold8 train & Fold9 train & Fold10 train & Fold1 train & Fold2 train \\
\hline Fold9 train & Fold10 train & Fold1 train & Fold2 train & Fold3 train \\
\hline Fold10 train & Fold1 train & Fold2 train & Fold 3 train & Fold4 train \\
\hline Fold1 train & Fold2 train & Fold3 train & Fold4 train & Fold5 train \\
\hline Fold2 train & Fold3 train & Fold4 train & Fold5 train & Fold6 train \\
\hline Fold3 train & Fold4 train & Fold5 train & Fold6 train & Fold7 train \\
\hline Fold4 train & Fold5 train & Fold6 train & Fold7 train & Fold8 train \\
\hline Fold5 train & Fold6 train & Fold5 train & Fold8 train & Fold9 train \\
\hline
\end{tabular}

Beberapa variasi pengujian akan dilakukan untuk mengetahui performa dari teknik klasifikasi. Variasi pengujian tersebut antara lain:

1. Pengaruh thinning terhadap performa

2. Pengaruh jumlah fitur terhadap performa dengan menggunakan proses zoning

Parameter yang digunakan untuk menentukan performa adalah akurasi yang dihitung menggunakan persamaan (18).

\section{A.1 Pengujian Skenario Pertama}

\section{A.1.1 Pengaruh Thinning Terhadap Performa}

Thinning merupakan proses penghilangan piksel terluar dengan cara iterative deletetion hingga menghasilkan sebuah piksel tulang (skeleten). Algoritma thinning secara iteratif 'menghapus' piksel-piksel pada citra biner, dimana transisi dari 0 ke 1 terjadi sampai dengan terpenuhi suatu keadaan dimana satu himpunan dari lebar per unit (satu piksel) terhubung menjadi suatu garis. Hal ini dimaksudkan untuk mengambil informasi yang penting dari citra. Pengaruh thinning terhadap performa sistem disajikan dalam bentuk grafik dituang pada Gambar 13 .

Gambar 13 menunjukkan bahwa proses preprocessing citra sebelum dilakukan proses thinning memiliki hasil akurasi $62.98 \%$, Setelah dilakukan proses thinning menggunakan metode Zhang-Suen nilai akurasi meningkat sebesar $11.17 \%$ dari nilai sebelumnya yaitu $75.25 \%$. Peningkatan hasil akurasi disebabkan oleh pengurangan jumlah noise pada citra dengan proses thinning sehingga citra yang dihasilkan berupa citra dengan informasi yang penting saja. Hasil tersebut menunjukkan bahwa proses preprocessing dengan menggunakan thinning ternyata dapat meningkatkan hasil akurasi klasifikasi citra, akan tetapi hasil yang diperoleh dari proses preprocessing tersebut belum mampu memberikan hasil yang maksimal dalam klasifikasi.

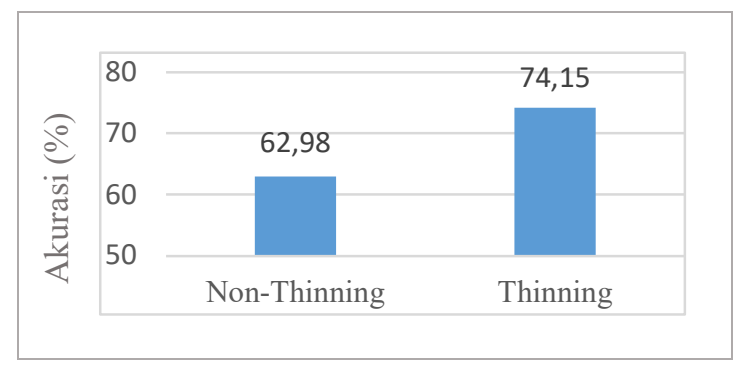

Gambar 13. Grafik performa menggunakan thinning

\section{A.1.2. Pengaruh Jumlah Fitur Terhadap Performa Dengan Menggunakan Proses Zoning}

Tujuan pengujian ini yaitu untuk mengetahui pengaruh penggunaan setiap fitur yang ada dengan performa sistem klasifikasi. Pada pengujian ini, menggunakan statistik fitur berupa 7 nilai Moment Invariant. Untuk mengetahui pengaruh fitur terhadap performa dilakukan manipulasi jumlah fitur dimana fitur yang digunakan yaitu 7 fitur, 28 fitur, 63 fitur dan 112 fitur. Jumlah fitur tersebut dilakukan dengan menggunakan proses zoning.

Zoning merupakan proses pembagian citra menjadi beberapa bagian yang sama. Pada penelitian ini data input yang digunakan berukuran $28 \times 28$ piksel. Kemudian dilakukannya pembagian citra menjadi 4 bagian, 9 bagian dan 16 bagian yang sama. Selanjutnya input data yang sudah terblok dimasukkan ke proses ekstraksi fitur. Dari proses tersebut diperoleh fitur sejumlah 4-16 kali dibandingkan dengan sebelum di zoning.

Dari proses tersebut didapatkan hasil klasifikasi dari beberapa fitur yang ditunjukkan pada Gambar 14 .

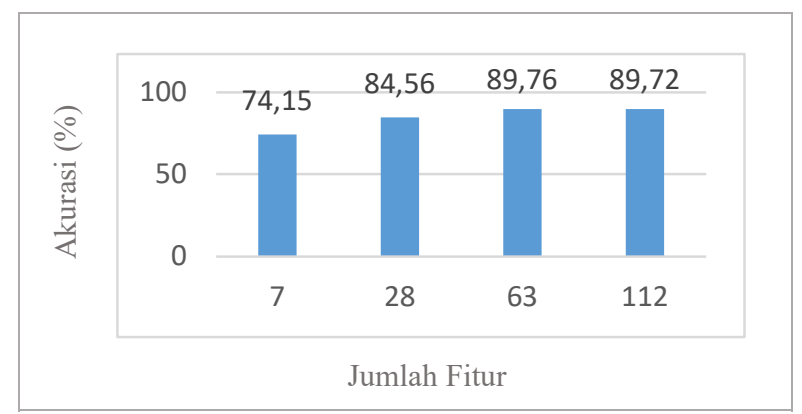

Gambar 14. Grafik performa menggunakan berbagai jumlah fitur

Gambar 14 menggambarkan bahwa akurasi meningkat seiring dengan bertambahnya jumlah fitur yang digunakan. Tingkat akurasi maksimum terdapat pada jumlah fitur 63 dengan hasil akurasi klasifikasi $89.76 \%$. Grafik pada Gambar 14 juga membuktikan bahwa proses zoning ternyata mampu meningkatkan hasil akurasi klasifikasi meningkat $15.61 \%$ dari hasil akurasi 
sebelumnya yaitu $74.15 \%$. Peningkatan hasil akurasi dengan zoning dikarenakan jika menggunakan zoning, citra dibagi menjadi beberapa bagian yang sama besar sebanyak sekian wilayah sehingga jumlah fitur yang dihasilkan dari proses zoning menjadi lebih banyak dibandingkan dengan hanya menggunakan 1 buah citra saja. Peningkatan jumlah fitur sama dengan meningkatkan informasi mengenai citra sehingga ciri-ciri citra menjadi lebih jelas.

\section{A.2. Pengujian Skenario Kedua}

\section{A.2.1. Pengaruh Thinning Terhadap Performa}

Pengujian kedua ini menggunakan proses K-Fold Cross Validation dengan $\mathrm{K}=10$. Jika total data input yang digunakan yaitu 2700 data maka data input untuk masingmasing K-Fold sejumlah 270 data yang terdiri dari masingmasing suku kata berisi 5 data. Pengaruh thinning terhadap performa sistem pengenalan disajikan pada pada Tabel II.

TABEL II. TABEL PERFORMA MENGGUNAKAN THINNING DENGAN K-FOLD

\begin{tabular}{|c|c|c|}
\hline \multirow{2}{*}{$\begin{array}{c}\text { Tahap Pengujian K- } \\
\text { Fold }\end{array}$} & Non-Thinning & Thinning \\
\cline { 2 - 3 } & Akurasi (\%) & Akurasi (\%) \\
\hline Tahap 1 & 67.58 & 76.43 \\
\hline Tahap 2 & 66.36 & 77.85 \\
\hline Tahap 3 & 71.68 & 76.40 \\
\hline Tahap 4 & 61.30 & 75.70 \\
\hline Tahap 5 & 62.64 & 78.04 \\
\hline Tahap 6 & 64.20 & 77.48 \\
\hline Tahap 7 & 63.68 & 77.16 \\
\hline Tahap 8 & 69.66 & 77.24 \\
\hline Tahap 9 & 63.36 & 78.18 \\
\hline Tahap 10 & 62.90 & 77.07 \\
\hline Rata-rata & 65.34 & 77.16 \\
\hline & & \\
\hline
\end{tabular}

Tabel II menunjukkan persentase akurasi data input dengan dan tanpa menggunakan thinning. Hasil persentase dari kedua pengujian tersebut ternyata membuktikan bahwa thinning mampu meningkatkan persentase akurasi sebanyak $11.82 \%$ dibandingkan tanpa menggunakan proses thinning.

\section{A.2.2. Pengaruh Jumlah Fitur Terhadap Performa Dengan Menggunakan Proses Zoning}

Tujuan pengujian ini yaitu untuk mengetahui pengaruh penggunaan setiap fitur yang ada dengan performa sistem klasifikasi. Pada pengujian ini, menggunakan statistik fitur berupa 7 nilai Moment Invariant. Untuk mengetahui pengaruh fitur terhadap performa dilakukan manipulasi jumlah fitur dimana fitur yang digunakan yaitu 7 fitur, 28 fitur, 63 fitur dan 112 fitur. Jumlah fitur tersebut dilakukan dengan menggunakan proses zoning. Dari proses tersebut didapatkan hasil klasifikasi dari beberapa fitur yang ditunjukkan pada Tabel III. Berdasarkan persentase akurasi yang ditunjukkan pada Tabel III, jumlah fitur terbaik dengan menggunakan pengujian K-Fold adalah fitur 112 dengan persentase yaitu $92.52 \%$. Tabel III juga menunjukkan bahwa dengan menggunakan pengujian KFold persentase akurasi meningkat sebanyak $15.37 \%$ dibandingkan dengan hanya menggunakan 7 fitur.
Berdasarkan kedua skenario pengujian yang dilakukan, hasil dari kedua skenario tersebut dituang pada grafik dalam Gambar 15.

TABEL III. TABel Performa Menggunakan Berbagai Jumlah FITUR DENGAN K-FOLD

\begin{tabular}{|c|c|c|c|c|}
\hline \multirow{2}{*}{$\begin{array}{c}\text { Tahap } \\
\text { Pengujian K- } \\
\text { Fold }\end{array}$} & 7 fitur & 28 fitur & 63 fitur & 112 fitur \\
\hline & $\begin{array}{c}\text { Akurasi } \\
(\%)\end{array}$ & $\begin{array}{c}\text { Akurasi } \\
(\%)\end{array}$ & $\begin{array}{c}\text { Akurasi } \\
(\%)\end{array}$ & $\begin{array}{c}\text { Akurasi } \\
(\%)\end{array}$ \\
\hline Tahap 1 & 76.43 & 88.81 & 92.40 & 92.62 \\
\hline Tahap 2 & 77.85 & 88.90 & 91.74 & 92.73 \\
\hline Tahap 3 & 76.40 & 89.78 & 92.00 & 92.12 \\
\hline Tahap 4 & 75.70 & 90.15 & 92.53 & 92.10 \\
\hline Tahap 5 & 78.04 & 90.64 & 91.78 & 93.21 \\
\hline Tahap 6 & 77.48 & 89.30 & 91.90 & 91.58 \\
\hline Tahap 7 & 77.16 & 88.92 & 92.82 & 91.63 \\
\hline Tahap 8 & 77.24 & 91.50 & 91.61 & 93.73 \\
\hline Tahap 9 & 78.18 & 90.23 & 91.03 & 93.06 \\
\hline Tahap 10 & 77.07 & 89.60 & 92.28 & 92.53 \\
\hline Rata-rata & 77.16 & 89.78 & 92.00 & 92.53 \\
\hline
\end{tabular}

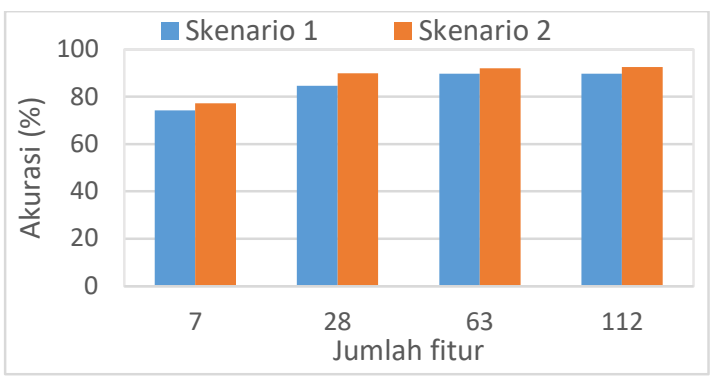

Gambar 15. Grafik performa 2 skenario pengujian

Sebaran data hasil klasifikasi yang ditunjukkan pada Gambar 15 menunjukkan bahwa hasil akurasi dengan menggunakan K-Fold lebih tinggi dibandingkan jika tanpa menggunakan K-Fold. Hasil akurasi K-Fold terbaik berada pada fitur 112 dengan nilai akurasi 92.52\%. Pada pengujian pertama, akurasi dari jumlah fitur 63 yaitu $89.76 \%$ menurun pada jumlah fitur 112 yaitu $89.72 \%$. Secara teori, semakin tinggi jumlah fitur yang diperoleh semakin tinggi pula identitas citra yang diketahui sehingga memudahkan dalam proses pengklasifikasian. Penurunan nilai akurasi pada pengujian pertama disebabkan karena SVM merupakan metode dengan sistem pembelajaran yang menggunakan ruang hipotesa berupa fungsi-fungsi linier, ketika SVM memprediksi kelas suatu data baru yang memiliki bobot berbeda dengan kelas yang seharusnya data tersebut berasa, maka SVM akan mengklasifikasikan data baru tersebut kedalam suatu kelas yang baru. Berdasarkan hasil yang ditunjukkan tersebut dengan kesusuaian teori mengenai metode SVM yang menjelaskan bahwa konsep klasifikasi dengan SVM adalah sebagai usaha mencari hyperplane terbaik yang berfungsi sebagai pemisah dua buah kelas data pada input space dimana hyperplane merupakan pemisah terbaik antara kedua kelas tersebut dapat ditemukan dengan mengukur margin hyperplane dan mencari titik maksimalnya. Teori tersebut membuktikan bahwa SVM dalam penelitian ini ternyata mampu melakukan klasifikasi lebih dari dua kelas dengan baik. 


\section{PENUTUP}

\section{A. Kesimpulan}

Berdasarkan penelitian pada BAB sebelumnya, maka dapat disimpukan bahwa:

1. Penelitian dilakukan terhadap beberapa jumlah fitur yaitu 7, 28, 63 dan 112 fitur. Pada skenario pengujian pertama, diperoleh fitur terbaik yaitu 63 fitur dengan nilai akurasi klasifikasi yaitu $89.76 \%$ dan pada skenario pengujian kedua diperoleh fitur terbaik yaitu 112 fitur dengan nilai akurasi klasifikasi yaitu $92.52 \%$.

2. Proses ekstraksi fitur moment invariant dengan penambahan proses thinning mampu meningkatkan akurasi klasifikasi dari $65.34 \%$ hingga $77.16 \%$ yaitu sebesar $11.82 \%$.

3. Penambahan jumlah fitur dengan proses zoning mampu meningkatkan akurasi klasifikasi dari $74.15 \%$ hingga $89.76 \%$ yaitu sebesar $15.61 \%$.

4. Proses Preprocessing dengan menggunakan thinning dalam sistem ini membantu mengurangi gangguan pada tulisan tangan suku kata sehingga dengan menggunakan thinning, preprocessing hanya melakukan pengambilan fitur-fitur yang dikehendaki.

5. Proses zoning dalam sistem ini membantu meningkatkan jumlah fitur hingga 4-16 kali dari jumlah fitur citra aslinya. Peningkatan jumlah fitur membantu meningkatkan identitas citra sehingga sistem ini mampu mengenali tulisan tangan suku kata aksara Sasak.

6. Pengklasifikasian data dimensi tinggi dengan pembagian kelas lebih dari dua pada SVM dalam penelitian ini ternyata mampu memberikan hasil akurasi yang baik.

\section{B. Saran}

Jika dilakukan penelitian lebih lanjut pada kasus ini dapat mempertimbangkan saran-saran dan perubahan sebagai berikut:

1. Modifikasi proses dapat dilakukan dengan menambahkan proses pengolahan citra lainnya seperti filtering dan sharpening atau pengolahan lainnya agar mendapatkan informasi citra yang lebih baik.

2. Metode ekstraksi fitur lainnya yang mampu memberikan jumlah fitur yang lebih banyak dari metode Moment Invariant.

3. Modifikasi parameter dapat dilakukan dengan mengubah ukuran alat tulis atau ukuran tulisan tangan aksara Sasak.

4. Diperlukan sistem yang indpenden terhadap translasi, rotasi dan penskalaan setelah dilakukan proses zoning.

5. Diperlukan pembagian kelas yang lebih lengkap lagi untuk kelas yang tidak dikenali sehingga sistem mampu memberikan hasil klasifikasi tidak dikenali untuk setiap citra input selain aksara Sasak.

\section{REFERENCES}

[1] Bahrie., H. Sudirman \& Lalu Ratmaja., (2013), Bahan Ajar Muatan Lokal, Gumi Sasak, KSU "Prima Guna", Lombok Timur.

[2] Hidayat, Akik., Rahmi Nur Shofa., (2016), Self Organizing Maps (SOM) Suatu Metode Untuk Pengenalan Aksara Jawa. Vol 1, No. 1.

[3] Wibowo, Madha Christian., I Dewa Gede Rai Mardiana., Sandy Wirakusuma, (2015), Pengenala Pola Tulisan Tangan Aksara Jawa Menggunakan Multi Layer Perceptron, STMIK AMIKOM. Yogyakarta.

[4] Hermanto, I Gede Rudy., Tjokorda Agung Budi Wirayuda., Retno Novi Dayawati ., (2008), Analisis Dan Implementasi Pengenalan Huruf Bali Menggunakan Modified Direction Feature Dan Jaringan Syaraf Tiruan, Fakultas Teknik Informatika, Universitas Telkom

[5] Wibowo, Aditya., Achmad Hidayatno., Ajub Ajulian, (2015), Pengenalan Huruf Jawa Tulisan Tangan Menggunakan Jaringan Saraf Tiruan Perambatan Balik Dengan Fuzzy Feature Extraction, Fakultas Teknik, Universitas Diponegoro, Semarang.

[6] Sholahuddin, A. (2012). Metode Moment Invariant dan Backpropagation Neural Network pada Pengenalan Wajah, Prodi Tenik Informatika, Universitas Padjadjaran Jatinangor.

[7] Ananggadipta, R., Hidayatno, A., \& Zahra, A. A., (2014), Pengenalan Huruf Alfabet Menggunakan 7 Moment Invariant Hu dan Jaringan Saraf Tiruan LVQ (Learning Vector Quantization), Jurusan Teknik Elektro, Universitas Diponegoro Semarang.

[8] Salambue, Roni., (2013), Pengenalan Pola Tanda Tangan dengan Metode Moment Invariant dan Euclidean Distance Roni Salambue, Jurusan Matematika, FMIPA, Universitas Riau.

[9] Andriati, S., 2011, Aplikasi Pengenalan Wajah Menggunakan Metode Support Vector Machine, Jurusan Teknik Elektro Politeknik Negeri Bali.

[10] Ilyarisma, R., (2015), Pengkasifikasian Warna Kulit Berdasarkan Ras Menggunakan Algoritma Support Vector Machine (SVM), Jurusan Teknik Elektro, Universitas Mataram.

[11] Zurnawita, Zulharbi Suar,(2009), Algoritma Image Thinning, Teknik Elektro, Politeknik Negeri Padang.

[12] David, (2011), Perancangan Perangkat Lunak Pengenalan Pola Karakter Menggunakan Jaringan Syaraf Tiruan Perceptron, Program Studi Teknik Informatika, Sekolah Tinggi Manajemen Informatika dan Komputer Pontianak, Kalimantan Barat. 